\title{
Demokratisk journalistik mellem politisk magt og afmagt ${ }^{1}$
}

\section{AF JøRN LOFTAGER}

Dagens nyhedsjournalistik prioriterer i dækningen af det politiske stof spillet om magten frem for substansen. Dermed svækkes grundlaget for et virkningsfuldt offentligt politisk ræsonnement. Samtidig er der mere end nogensinde brug for et sådant ræsonnement. Artiklen skitserer en sociologisk forståelse af dilemmaet. Det generelle argument er, at en transformation, fra et samfund domineret af en hierarkisk klassedifferentiering til et samfund domineret af en horisontal funktionel differentiering, har medført nye betingelser for udøvelsen af politisk magt. På den ene side er muligheden for direkte politisk styring blevet svækket. På den anden side har udviskede politiske identiteter tvunget de politiske aktører til, at gøre sig selv synlige i vælgernes øjne ved, at udvise magt og handlekraft. Resultatet er en vækst i symbolpolitik, taktik og spin, der udfordrer journalistikkens demokratiske rolle.

Første indslag i radioens P1 Morgen den 21. juni 2006 drejede sig om den velfærdsreform, der var indgået et bredt politisk forlig om dagen før. Ud fra et væsentlighedskriterium forekommer dette redaktionelle valg både selvfølgeligt og forventeligt. Forventelig var også den anlagte vinkling af historien, nemlig om Socialdemokraternes medvirken i forliget, ville bringe Helle Thorning Schmidt tættere på statsministerposten. Mere tvivlsomt er det, om denne vinkling også var den selvfølgelige. Ville det ikke ud fra et væsentlighedskriterium, have været mere nærliggende at fo- 
kusere på velfærdsreformens indhold og begrundelse?

Dette eksempel på journalistisk prioritering af spillet om magten frem for substansen er langt fra enestående. For at blive ved det 'seriøse' P1 kan tilsvarende nævnes Orienterings behandling af offentliggørelsen af Strukturreformkommissionens betænkning den 9. januar 2004. Her samlede interessen sig om, hvordan Socialdemokraterne og specielt Mogens Lykketoft kunne tænkes at forholde sig til en kommunalreform med henblik på at forbedre chancerne for at vinde det forestående folketingsvalg. At dette ville være Lykketofts primære handlingsmotiv blev tilsyneladende antaget som noget helt trivielt.

Mere tungtvejende vidner også en analyse af avisernes dækning af samme sag om en svigtende interesse for substansen (Loftager 2006). Analysen omfatter fire landsdækkende aviser i ugen efter offentliggørelsen af Strukturkommissionens betænkning, og mens behandlingen er præget af stor mangfoldighed med hensyn til både antal artikler, emner, vinklinger og kilder, er den stort set renset for det grundlæggende spørgsmål, om behovet for en så omfattende reform - Danmarkshistoriens største, som den er blevet betegnet. Kun i et par tilfælde, og da i form af indlæg udefra, problematiseres fornuften i projektet. Det var der ellers god grund til. Tidligere kommissioner havde konkluderet, at den eksisterende struktur i hovedsagen var velfungerende, og toneangivende politikere, blandt dem den nuværende indenrigsminister, havde afvist, at der var et dokumenteret behov for en reform. Det samme gjorde nu stort set hele den kommunalpolitiske ekspertise, hvilket aviserne imidlertid ikke tog notits af. Og at den del af ekspertisen, der sad med i kommissionen, følte sig foranlediget til at fremkomme med en mindretalsudtalelse, blev man som læser af Jyllands-Posten, Politiken, Berlingske Tidende eller Information heller ikke underrettet om i den pågældende uge. Hvad aviserne derimod flød over med, var alle magtspillene om 'det nye Danmarkskort'.

Når der på demokratiets vegne er grund til at bekymre sig over en udvikling, hvor interessen for det sagligt, indholdsmæssige aspekt af politikken viger for en interesse for spillet om magten, skyldes det den udhuling af det offentlige ræsonnement, som kan blive resultatet. Ganske vist er realiteten af dette fænomen, 'det 
offentlige ræsonnement', omdiskuteret, ligesom det ikke indgår med lige stor vægt $\mathrm{i}$ alle forestillinger om demokratiet. Men der synes dog at herske en udstrakt enighed om, at offentlighed og offentlig diskussion og deliberation udgør hovedhjørnesten i demokratiet, og demokrati som samtale er en rodfæstet del af dansk politisk kultur med Hal Koch som prominent fortaler (jf. Loftager 2004: 73-75).

Dertil kommer, at der mere end nogensinde synes at være brug for en levende offentlig diskussion til kvalificering af de politiske beslutninger. I hvert fald er det, hvad der skal argumenteres for i nærværende artikel. Tesen er kort sagt, at ændrede samfundsstrukturelle vilkår skaber et øget behov for en virksom offentlig diskussion og meningsdannelse. Mere konkret drejer det sig om udviklingen fra et samfund domineret af gruppe- og klasseopdelinger til et samfund domineret af horisontale opdelinger mellem autonome funktionssystemer i tilknytning til en stadig mere vidtgående arbejdsdeling og specialisering. Hertil svarer udvikling af nye politiske opgaver og udfordringer. Tidligere samlede politikken sig primært om at finde løsninger på fordelingsmæssige spørgsmål og konflikter mellem forskellige sociale grupperinger og på grundlag af forholdsvis veldefinerede politisk ideologiske skillelinier. I stedet er det nu i stadig højere grad blevet opgaven, at koordinere samspillet mellem relativt selvstændige funktionssystemer. Det betyder fremkomsten af problemer og udfordringer for den politiske styring og magtudøvelse, som de overleverede politiske ideologier får stedse sværere ved, at levere svar på. Og det er i fraværet af færdigsyede svar og løsninger, at behovet vokser for en fortsat og omfattende offentlig diskussion.

Realiseringen af et udfoldet offentligt ræsonnement ser imidlertid ud til at vanskeliggøres af udviklingstendenser i det politiske system selv. Her er det tilsyneladende svært for partierne at 'indrømme' den usikkerhed og kompleksitet, som faktisk præger de problemer, de stilles overfor. I en situation med udviskede ideologiske forskelle og altid begrænset opmærksomhed i det offentlige rum tilskyndes partierne til at tænke og handle strategisk i konkurrencen om vælgernes gunst. Det kan typisk ske ved, at skabe synlighed og vinde opmærksomhed gennem klare budskaber og udvisning af beslutsomhed og handlekraft. Kort sagt er po- 
litikerne i kampen om magten tilskyndet til, at udvise en magt over tingene, som de i virkeligheden ikke har eller kan have.

Er der hold i denne diagnose, står medierne og specielt deres ideal om, at være demokratiets vagthund over for en alvorlig udfordring. Deres tilsyneladende koncentration om spillet snarere end substansen, kan nok siges at udgøre en realistisk afspejling af logikken i det politiske system. Samtidig passer den som fod i hose til de nyhedskriterier, der ifølge medieforskningen er kommet til at præge den selvstændiggjorte medieinstitution. På den baggrund er det ikke svært, at forestille sig, hvordan en selvforstærkende dynamik mellem parti- og mediesystem vil kunne resultere i en fordummelsens spiral og virkeliggøre det offentlighedens forfald, der i så mange år har været advaret imod. I det mindste er det en risiko, der bør tages alvorligt og ikke mindst af de medier og journalister, som fortsat ser formidlingen af et offentligt ræsonnement som en hovedopgave.

Jeg skal starte med at skitsere, hvordan den klassiske forestilling om offentligheden hos Habermas, som fortsat eksplicit eller implicit tjener som grundlag for mediers og journalisters demokratiske selvforståelse, er indskrevet i en forståelse af samfundet som primært klassedifferentieret. Dernæst antydes de konsekvenser for offentlighedens rolle, der følger af en udvikling, hvor en funktionel differentiering af samfundet bliver dominerende. I det sidste afsnit peges på journalistikkens centrale betydning for prioriteringen mellem politisk spil og substans - såvel i medierne som i politikken.

\section{Offentlighedens ide og forfald}

Magtens erstatning af fornuften eller endog sandheden som politikkens grundlag. Intet mindre end dette er det centrale i forestillingen om en politisk fungerende offentlighed eller et offentligt politisk ræsonnement. Det fremgår af Habermas' historieskrivning i standardværket Borgerlig Offentlighed fra 1962 (dansk /norsk udgave 1975). Tiden er 1700-tallet, og den fremvoksende offentlighed er borgerlig i dobbelt forstand. For det første er dens deltagere lige som borgere - borgerlige. I diskussionerne, som de bl.a. udspandt sig i Londons kaffehuse, skulle der sættes paren- 
tes om forskelle i status og social baggrund; her skulle alene argumenterne tælle. Det revolutionerende nye ideal er, at loven ikke længere skal basere sig på magten, men på sandheden, som den tænkes at vokse ud af det offentlige ræsonnement (Habermas 1975: 50). Offentligheden er imidlertid også borgerlig i den betydning, at rollen som borger er forbeholdt det ejendomsbesiddende borgerskab - der er sammenfald mellem 'citoyen' og 'bourgeois'. Og begrundelsen er, at alene ejendomsbesiddelse kan garantere den uafhængighed og dannelse, der er forudsætningen for at tage del i det offentlige ræsonnement og derigennem bidrage til at forlene politikken med fornuftens kvalitetsstempel.

Der var således fra starten tale om en modsætning mellem offentlighedens teori og praksis. På den ene side var idealet universelt, idet ‘sandheden' måtte forudsætte, at alle argumenter kunne afprøves. På den anden side var det i praksis kun et lille mindretal, der kunne deltage. Ud fra datidens forudsætninger kunne denne modsætning forsøges opløst gennem en tro på et fremtidigt samfund af små-producenter. Under den fuldkomne konkurrences lige vilkår ville alle garanteres mulighed for at opnå økonomisk uafhængighed og dermed adgang til offentligheden. Siden afsløredes det illusoriske i denne fremtidsforestilling. I stedet voksede et kapitalistisk klassesamfund frem præget af modsætninger, der ikke lod sig formidle af rationel diskussion, og som derfor undergravede de demokratiske lighedsidealer.

Samtidig må det understreges, at offentlighedsidealet og den tilhørende forestilling om politik som rationel problemløsning var mere end blot og bar ideologi. Som et sigende udtryk herfor beskriver Habermas, hvordan det britiske parlament tvinges til at gøre de hidtil hemmelige møder åbne og forhandlingerne offentligt tilgængelige. Ved overgangen til det 19. århundrede var det offentlige ræsonnement udviklet så vidt, ,at det i rollen som permanent kritisk kommentator definitivt havde brudt parlamentarismens eksklusivitet og udviklet sig til delegaternes officielt beskikkede diskussionspartner“ (Habermas 1975: 61). Parlamentets diskussioner kan ikke længere afgrænse sig fra den offentlige mening, men må forstå sig selv som en del heraf.

Et hurtigt blik på dansk politisk historie bekræfter både, at 
ideen om et offentligt ræsonnement også her var i omløb, og at den i betydelig udstrækning afspejlede politiske realiteter (jf. Loftager 2004: 56 ff). For eksempel udsendte den daværende danske „statsminister“, overhofmarskal A.G. Moltke, i 1755 en offentlig appel til alle „retskafne patrioter“ om at indsende forslag, „som tiener til at vedligeholde Landets Velstand, formindske Udgifterne, formere Indkomsterne“. Og appellen blev i vid udstrækning fulgt, idet borgerne reagerede med indsendelse af et væld af forslag, hvoraf de mest værdifulde blev publiceret i otte bind af Danmarks og Norges Oeconomiske Magazin i årene fra 1757 til 1764 (Feldbæk 1991: 117-118).

Dette eksempel på en politisk offentlighed i funktion afspejler en enevælde, der ikke blot blev forstået som oplyst i kraft af regentens oplysning, men også i betydningen „opinionsstyret“ (Seip 1958). Den enevældige konges opgave var at styre landet $i$ overensstemmelse med det fælles bedste, som det kom til udtryk i den offentlige debat og meningsdannelse. Og dette var vel at mærke ikke udelukkende udtryk for en ideologisk tilsløring af et faktisk diktatur. I praksis medvirkede offentligheden i den meget dynamiske reformlovgivning, der prægede den danske enevælde, og som er blevet betegnet som enestående ikke alene i dansk historie, men også i verdenshistorien - og som sandsynligvis har været med til at skabe en grundlæggende tillid til statens rolle som reformator (Knudsen 2001: 61).

Forestillingen om politik som rationel problemløsning baseret på et offentligt ræsonnement svækkedes i anden halvdel af 180otallet og videre frem $\mathrm{i}$ kølvandet på den kapitalistisk organiserede industrialiserings gennemgribende forandringer. Såvel i teori som i praksis kom bestemte gruppe- og klasseinteresser til at dominere i en sådan grad, at ideen om et offentligt ræsonnement som politikkens og demokratiets omdrejningspunkt fortonede sig i det utopisk uvisse. Det klassiske danske fire-partisystem illustrerer til fulde interessernes gennemslag (Elklit 1986), og tilsvarende indforskriver hovedparten af det 20. århundredes politologi, herunder dansk statskundskab, sig til en forståelse, efter hvilken politik essentielt drejer sig om den autoritative fordeling af værdier - "Who gets what, when and how?", som det sigende er formuleret af den amerikanske politolog, Harold D. Lasswell. 
Når Habermas' historie om offentligheden er en forfaldshistorie skyldes det grundlæggende denne interessernes erobring af det politiske rum som følge af kapitalismens udvikling. Men det er ikke hele historien. Politik som kamp mellem særinteresser efterlader stadig den mulighed, at offentlighedsprincipperne kan blive styrende for de organisationer, der repræsenterer interesserne. Interesseorganisationer og politiske partier kan såvel internt som i deres indbyrdes samspil fungere demokratisk. Også på dette punkt er Habermas' diagnose imidlertid pessimistisk. I stedet for et pluralistisk system med mange konkurrerende, medlemsstyrede organisationer ser han en bevægelse mod et korporatistisk lukket politisk rum, der systematisk vender styringsrelationerne, så de går oppefra og ned. Således fremstår partierne som professionelt ledede apparater, der er vokset sammen med de offentlige myndigheder, og som

„etablerer sig over den offentlighed, som de engang var instrumenter for. ... Publikum som sådan bliver kun sporadisk trukket ind i dette magtens kredsløb og da blot kun til akklamationsformål. ... Publicitet bliver så at sige udfoldet ovenfra for at skaffe bestemte positioner goodwill ... (den) tjener lige så meget til manipulation af publikum som til legitimation for publikum. Kritisk publicitet fortrænges af manipulativ publicitet“ (Habermas 1975: 164-165).

\section{En revideret fortælling om offentligheden}

Det dybt pessimistiske billede af en nærmest afviklet offentlighed undergår i Habermas' senere forfatterskab kraftige revisioner. På den ene side konstateres, at forfaldsbeskrivelsen på centrale punkter er blevet dementeret af den efterfølgende udvikling. På den anden side reformuleres selve ideen om en politisk fungerende offentlighed.

Habermas opgiver skrækvisionen om et lukket, kontrolleret korporatistisk samfund, hvor offentligheden har mistet enhver kritisk funktion, og borgerne er forvandlet til apatiske forbrugere af en manipulerende medie- og underholdningsindustris linde strøm af ligegyldigheder. Den stemmer af selvindlysende årsager 
ikke overens med de omfattende politiske forandringer og nydannelser, der kom til at karakterisere tiden fra de sene 196oere og frem. Ifølge sin egen forklaring havde Habermas undervurderet betydningen af det stærkt voksende generelle uddannelsesniveau, af mulighederne for kulturelle mobiliseringer og dannelse af kritiske holdninger og mere generelt den dermed forbundne udvikling af en differentieret offentlighed hinsides de gamle klassedelinger (Habermas 1992: 438).

Men som sagt drejer det sig også om en præcisering af offentlighedsidealet selv, og revisionen bunder her i en ændret opfattelse af, hvordan det moderne samfund overordnet er skruet sammen. Selvkritisk understreger Habermas, at han i Borgerlig Offentlighed var for præget af en hegeliansk-marxistisk totalitetsforestilling med et tilhørende ideal om et fremtidigt gennemsigtigt og total-demokratisk styret samfund. Med tydelig inspiration fra systemteorien (Luhmann) fremhæves det, at koordinering og integration i det moderne samfund aldrig alene vil kunne foregå demokratisk endsige dialogisk, men vedblivende vil beholde en også systemisk karakter (ibid.: 443). Både markedsmekanismen og handlingskoordination gennem politisk-administrativ magtudøvelse er kommet for at blive. Dernæst præciseres det, at der aldrig kan være en direkte forbindelse mellem det offentlige ræsonnement og beslutningerne i det politiske system. Et sådant ræsonnement regerer ikke. Det gør de dertil indrettede institutioner - den administrative magt. Dermed lægges afstand til de deltagelsesdemokratiske idealer, der spøger mellem linierne i Borgerlig Offentlighed, og hvor det bedste demokrati er det totale demokrati.

Opfattelsen er imidlertid fortsat den, at det offentlige ræsonnement er den primære kilde til politisk legitimitet. Legitimiteten beror på de grunde, der gives for de politiske beslutninger, og offentlighedens såkaldte kommunikative magt udøves gennem dens kontrol over de begrundelser, der er tilgængelige for det administrative apparat (Eriksen \& Weigård: 286). „Den kommunikativt frembragte legitime magt $i$ offentligheden kan påvirke det politiske system på den måde, at det overtager den pool af grunde, ud fra hvilke de administrative beslutninger må rationaliseres" (Habermas 1992a: 623). 
Selv om Habermas' revisioner af forfaldshistorien er markante, er spørgsmålet, om de er markante nok? For det første kan man spørge, om ikke tesen om udviklingen fra politik som rationel problemløsning til ren interessekamp trænger til en mere omfattende nyvurdering? For det andet, om ikke systembeskrivelsen af samfundet bør gå endnu videre?

At forskellige interesser med rod i samfundets strukturelle opdelinger kom til at dominere politikken i størsteparten af det 20. århundrede, lader sig ikke benægte. Men spørgsmålet er, om ikke kampen mellem særinteresserne hele vejen igennem var knyttet til og delvist udfoldede sig i en fungerende offentlighed og derved også involverede bredere almeninteresser. På baggrund af den danske politiske historie synes det oplagt at være tilfældet. Specielt når der skal gøres rede for de længere udviklingsstræk, er det nærliggende at indlæse vigtige elementer af erfaringsdannelse og læreprocesser medieret af den politiske offentlighed. De politiske aktører har taget ved lære og ændret opfattelser under indtryk af indvundne erfaringer - og ikke blot, fordi de tvinges dertil. I det såkaldte samarbejdende danske folkestyre er der indgået vigtige forlig henover midten som for eksempel Kanslergadeforliget i 1933 eller vedtagelsen af den almindelige folkepension i 1956. Og reformerne har fået lov at blive stående i den udstrækning, de har vist sig at have konsekvenser, hvis formålstjenlighed ingen har villet eller kunnet benægte.

Den brede enighed om „velfærdsdemokratiet“ baseret på en almen accept af såvel en (reguleret) markedsøkonomi som en udbygget velfærdsstat (Rasmussen, 1969), der opstod i løbet af 196oerne, behøver derfor ikke at blive tolket som indvarslingen af et teknokratisk mareridt, sådan som det sker hos Habermas i Borgerlig Offentlighed. Tværtimod synes der, at være grund til at hæfte sig ved et væsentligt omfang af 'ægte', det vil sige ikke-manipuleret, men erfaringsbaseret og offentlighedsbundet, konsensus.

Dermed skal den demokratiske karakter af datidens politik på ingen måde forgyldes. Først og fremmest var der en betydelig større ulighed i den politiske deltagelse end i dag, og naturligvis har taktiske og strategiske hensyn i kampen om (regerings)magten hele tiden spillet en hovedrolle. Men på grund af stærkere og 
mere distinkte, ideologisk forankrede identiteter, målsætninger og programmer samt flere partimedlemmer og kernevælgere var behovet for synliggørelse og politisk marketing mindre. Og det at gå efter magten var ensbetydende med at gå efter realisering af relativt kendte og rodfæstede ideer om, hvordan tingene skulle indrettes til fordel for nogle og ulempe for andre.

\section{Politisk styring og funktionel differentiering}

Historisk var etableringen af en offentlighed, som nævnt, knyttet til kapitalismens fremvækst. Borgerrollens almene og universelle karakter, bevidstheden herom og retsstatens civile rettigheder og senere de demokratiske rettigheder indebar et radikalt brud med det standsopdelte feudale samfund. Men i samme bevægelse som kapitalismen på den måde lagde grunden til demokratiet, forhindrede dens klassedeling, at det kunne komme til udfoldelse. I hvert fald var det en hovedpointe hos Marx, at reel demokratisk frihed og lighed ville forblive en illusion, så længe kapitalismen med dens asymmetriske magtrelationer eksisterede. Heri tog han dog fejl. Blandt andet i kraft af velfærdsstatens sociale rettigheder viste det sig muligt at skabe sameksistens mellem den dynamik og de strukturelle modsætningsforhold, der karakteriserer kapitalismen, og et stadig mere lige medborgerskab og reelt demokrati, inklusive en fungerende offentlighed. Det er ikke mindst de nordiske velfærdsstater udtryk for.

Sideløbende er samfundets klasseopdeling i stigende grad blevet overlejret af en 'funktionel differentiering'. Udtrykket skyldes den tyske sociolog og systemteoretiker Niklas Luhmann, som hævder, at det moderne samfunds væsentligste form for opdeling eller differentiering ikke er den vertikale mellem forskellige lag, klasser eller grupper, men den horisontale opdeling mellem forskellige funktionssystemer - politik, ret, økonomi, uddannelse, kunst, religion etc. (Luhmann, 1999). Det er den fortsatte specialisering og arbejdsdeling ('uddifferentiering') snarere end klassekamp, der udgør den vigtigste motor for samfundsudviklingen.

For Luhmann er det en central pointe, at disse systemer er selvregulerende, hvorfor de også unddrager sig politisk styring i den 
forstand, at det ikke lader sig gøre gennem politiske beslutninger direkte at sikre, at systemerne producerer ydelser af bestemt indhold og kvalitet (Andersen 2006). Fx kan det politiske system nok ønske og kræve, at danske skoleelevers opnår gode læseevner, men at sikre, at det sker, er en pædagogisk og ikke en politisk opgave (Andersen 2004). En erkendelse af, at dette er vilkårene, kan siges at komme til udtryk i for eksempel folkeskolens metodefrihed eller i det såkaldte „armslængde-princip“, som betyder, at kunststøtte ikke bevilges af politikere, men af personer med særlig kunstindsigt. Princippet om forskningsfrihed på universiteterne kan nævnes på linie hermed. Dette princip kan det politiske system vælge at tilsidesætte, ved at kræve, at der skal forskes efter bestemte metoder og under anerkendelse og anvendelse af bestemte teorier - sådan som det har været set i totalitære regimer. I givet fald vil det være udtryk for, at forskningssystemets kode sand/falsk tilsidesættes til fordel for det politiske systems kode magtover/underlegenhed. Men en sådan magtanvendelse kan ikke garantere, at der vindes ny erkendelse - sand erkendelse lader sig som sådan ikke skabe gennem politiske beslutninger.

Den egentlige styring må derfor overlades til systemerne selv og til den selvkontrol, der udfoldes eller kan udfoldes i de tilknyttede deloffentligheder. Men samtidig med at politisk styring på den måde er umulig, kan den også være nødvendig. Det skyldes, at de forskellige autonomt fungerende systemer er afhængige af hinandens ydelser. Økonomien kan ikke fungere, hvis ikke fx retssystemet er der, til at sikre indgåede kontrakters overholdelse, ligesom det økonomiske systems funktion også fx er betinget af uddannelsessystemets ydelser i form af bestemte kvalifikationer. Tilsvarende er der mange andre åbenlyse gensidige afhængigheder, og der er ingen garanti for, at det ene system leverer det, andre har brug for. Hvis ikke det er tilfældet, kan det være 'nødvendigt' med politisk styring, og der vil typisk rejse sig krav om politiske indgreb.

Problemet er, som antydet, at denne styring kun havde karakter af indirekte påvirkninger, der udefra 'irriterer' systemet til af sig selv, at ændre på de ydelser, det producerer. Som illustrerende eksempel kan nævnes styringen af den danske folkeskole. Her har en række internationale undersøgelser af danske elevers 
kundskaber og færdigheder på centrale felter som læsning og naturfag afsløret et forholdsvis lavt niveau. Og det var vel at mærke efter, at skolen havde været genstand for omfattende politisk styring, ikke mindst i form af folkeskoleloven af 1993 - verdens bedste folkeskolelov, som den dengang blev udnævnt til. I den aktuelle diskussion er der mange meninger om, hvor galt det står til, men langt de fleste i skoleverdenen, herunder Danmarks Lærerforening, har tilsluttet sig bestræbelserne på at forbedre de faglige kundskaber og ikke mindst læsefærdighederne. Folketinget har reageret ved igen at vedtage en ny folkeskolelov, der bl.a. indeholder krav om gennemførsel af ensartede tests af eleverne, og der er ligeledes indført krav om udarbejdelse af såkaldte elevplaner til registrering og kontrol af den enkelte elevs faglige udvikling.

Resultaterne af de seneste politiske styringstiltag er det endnu for tidligt at sige noget om, men så meget står klart, at det naturligvis er stærkt begrænset, hvor meget de i sig selv vil forbedre niveauet af fx elevernes læsefærdigheder. Derimod er der næppe tvivl om, at den bredere offentlige diskussion om for mange dårlige læsere blandt danske skoleelever for længst har foranlediget en kraftig opprioritering af læseundervisningen rundt om på landets skoler. Principielt sagt er der på de enkelte skoler, deres ledelser og hos de enkelte lærere foregået en omvurdering af, hvad undervisningsopgaven nærmere går ud på. Resultatet vil sandsynligvis være bedre læsere i fremtiden.

I sammenhængen her er det vigtigste imidlertid, at mærke sig, at det i så fald ikke primært skyldes en direkte politisk styring, men ændringer indefra foranlediget af en (offentlig) 'irritation' udefra af folkeskolesystemets kommunikation og selvforståelse. På den måde kan eksemplet illustrere de vilkår for politisk styring, som følger af samfundets funktionelle differentiering, ligesom det kan illustrere den rolle, offentligheden har at spille. For det første fordi man må forstå de forskellige ydelser som er bundet til kommunikationen og diskussionen i de pågældende systemer. Når man som borger almindeligvis kan have tillid til systemerne beror det ikke i første række på, at de er underlagt politisk kontrol, men på, at der foregår en løbende kritisk diskussion af det, der foregår. Det klareste eksempel er måske universite- 
terne, hvor det turde være temmelig indlysende, at kvaliteten af forskningen først og fremmest sker i kraft af gensidig, offentlig kritisk granskning. Men det gælder også generelt for det, den engelske sociolog, Anthony Giddens, har kaldt ekspertsystemer, og som spiller en hovedrolle i det (sen)moderne samfund (Giddens 2003).

Dernæst er ikke blot ekspertsystemernes deloffentligheder vigtige; det er også offentligheden i bestemt form. Det vil sige den store offentlighed, hvor temaer og diskussioner selvfølgelig altid handler om noget bestemt, men hvor også lægfolk kan deltage og dermed være med til at påvirke (irritere) de specialiserede offentligheder. En sådan påvirkning vil vedvarende være påkrævet for at sikre, at systemerne så at sige producerer det, der er brug for. Folkeskolens situation kan igen anføres som illustrerende eksempel. Det, der her 'gik galt', kan nærliggende tolkes som udslag af skoleoffentlighedens utilstrækkelige realitetssans, hvilket igen må ses i sammenhæng med, at en dominerende (reformpædagogisk) diskurs gennem mange år havde fået lov at stå relativt uimodsagt (jf. Loftager 2004: kap. 5).

Med andre ord vil der vedvarende være brug for, at diskussionerne holdes åbne, og det kan betragtes som en hovedopgave for det politiske system at bidrage til, at det sker. Men kan man således teoretisk begrunde, at en indirekte styring gennem påvirkning af deloffentligheder vil være effektiv, er det af selvfølgelige grunde svært at angive, hvordan det kan ske i praksis. Under alle omstændigheder synes det dog lige så selvfølgeligt at måtte forudsætte en høj grad af offentlighed omkring de politiske beslutningsprocesser. Alene dette kan sikre, at mangfoldigheden af informationer om mulige konsekvenser kan blive taget i betragtning.

Problemet er, at det politiske system, som det fungerer, synes at have svært ved at yde den form for indirekte styring. Det skyldes på den ene side, at systemet og i særdeleshed partierne har rod i en situation, hvor det primært drejede sig om at skabe kompromisser i forbindelse med den fordelingspolitiske udskæring af samfundskagen, og hvor det i sidste ende var et spørgsmål om magt til (direkte) at gennemtrumfe bestemte interesser. På den anden side skyldes det også, at det politiske systems funktionslo- 
gik selv er blevet selvstændiggjort. Kort sagt betyder det, at systemet fungerer mere rent i overensstemmelse med sin kode om magt/ikke magt eller regering/opposition. Magten, som et mål i sig selv, kommer til, at dominere over magten, som middel til at gennemføre bestemte politiske målsætninger og projekter. Den 'gode' og 'rigtige' politik er der ikke på forhånd, men skal hele tiden skabes med henblik på at sikre popularitet, stemmer og magt (jf. Petersson 2000).

I princippet kunne denne indholdstømning af politikken udmærket være forenelig med de skitserede vilkår for politisk styring i det funktionelt differentierede samfund. Praksis synes dog at fortælle noget andet. Dels viser det sig, at offentligheden ofte reelt udelukkes fra at gøre sig gældende i forbindelse med vigtig reformlovgivning. Jeg har således selv påvist, hvordan reformer igennem de seneste årtier i stigende omfang er blevet gennemført som led i finanslovsaftaler og dermed i praksis uden for offentlighedens søgelys (Loftager 2004: kap. 8). Dels lægger de taktisk og strategisk begrundede krav til politikerne - og måske også til embedsværket - om synlighed, positionering og handlekraft op til en ganske anden direkte og indgribende politisk styring. Paradokset er da, at det politiske systems selvstændiggjorte konkurrencelogik tilsyneladende tvinger aktørerne til at spille rollen som almægtige, der gennem storstilede reformer formår at forme og kontrollere virkeligheden efter forgodtbefindende - selv om det er aldeles illusorisk. Og når det kan lade sig gøre, hænger det sammen med, at effekterne af sådanne reformer ofte vil række langt ud over næste valgdato. Det kan også være forklaringen på, at væsentlige reformer gennemføres på et endog meget spinkelt analyse- og dokumentationsgrundlag. Som det seneste eksempel kan nævnes fusionsbølgen inden for de videregående uddannelser (jf. Christensen 2006).

Imidlertid er der ingen nødvendighed knyttet til det politiske systems manglende udnyttelse af de muligheder for en aktiv og medvirkende offentlighed, som den opblødte klassestruktur og afideologiseringen har afstedkommet. Det ses alene af, at der mellem de politiske aktører på dette punkt kan iagttages forskelle, der klart gør forskel. Inden for det anlagte systemteoretiske perspektiv må det antages, at omfanget af denne udnyttelse 
afhænger af andre systemers måder at fungere på, og af helt central betydning er her mediesystemet.

\section{Journalistikkens nøgleposition}

Med den indledningsvise påstand om, at medierne i stigende grad prioriterer det politiske spil frem for substansen, kan det umiddelbart virke omsonst at forvente, at mediesystemet vil kunne bidrage til, at det politiske system i højere grad tager offentligheden alvorligt. Er mediesystemet ikke snarere at betragte som en del af problemet? Jeg skal i dette afsnit argumentere for, at mens det umiddelbare svar til dels må være bekræftende, er det ikke ensbetydende med, at det ikke kan være anderledes. Uanset eksistensen af ensartede nyhedskriterier kan der også blandt medierne iagttages betydningsfulde forskelle med hensyn til den måde, hvorpå der bidrages til formidlingen af det offentlige ræsonnement. Og også mediesystemet er naturligvis påvirkeligt gennem strukturelle koblinger til andre systemer som $\mathrm{fx}$ uddannelsessystemet.

For det kritiske blik ser Habermas' analyse af mediernes rolle i Borgerlig offentlighed fortsat besnærende relevant ud. Under overskriften „Fra kulturroesonnerende til kulturkonsumerende publikum" (p. 156) beskrives, hvordan kommercielle hensyn bliver mere og mere fremtrædende, og hvordan „maksimering af afsatning betales med afpolitisering af indhold“ (p. 157). Aviserne mister tilknytningen til partierne, og forbrugerorienteret stof vinder frem på bekostning af politisk relevante nyheder, og disse selv „udstyres med underholdningsindustriens inventar“ (p. 158). Dette videreføres i forstærket udgave i de nye elektroniske medier, som "tendentielt erstatter virkelighedssans med konsummodenhed og snarere forleder til upersonlig forbrug af afspoendingsstimuli end vejleder til offentlig brug af fornuften“ (p. 158). Kort sagt er de moderne medier og specielt de elektroniske effektive instrumenter for den „strukturforvandling“, der gør publikum til objekt for manipulation snarere end subjekt for lovgivning og myndighedskontrol.

Også på dette punkt trænger forfaldshistorien dog til revision. Alene af den grund, at flere af de former for politisk deltagelse, der 
i de seneste årtier har sat væsentlige problemfelter på den offentlige dagsorden, i høj grad har fungeret gennem medierne. Samtidig er de pessimistiske vurderinger dog interessante, for så vidt som nogle af de udviklingstræk, de henviser til, åbenlyst gør sig gældende og dermed vidner om en modsætningsfyldt situation.

Centralt står i den forbindelse spørgsmålet om graden af mangfoldighed i nyhedsdækningen. Forekomsten af og spændinger mellem forskellige synspunkter, perspektiver, informationer og argumenter er det, som giver liv til det offentlige ræsonnement. Det offentlige rums medieformidlede virkelighed vil nødvendigvis være en redigeret virkelighed i den trivielle forstand, at der altid vil være uendeligt meget mere at informere om og diskutere og problematisere, end medierne er i stand til at rumme og borgere og politikere i stand til at kapere. Derfor er spørgsmålet ikke om, men hvordan medierne fungerer som filtre i offentlighedens kommunikationskanaler. Ensrettes og homogeniseres informationsstrømme og diskussioner med konformitet som resultat, eller gives der plads til den mangfoldighed, der er forudsætningen for et dynamisk offentligt ræsonnement, som kan bidrage til 'rationaliseringen' af den politiske problemløsning?

Ses på avisernes nyhedsdækning, er der med det stærkt reducerede antal dagblade sket en markant nedgang i den strukturelle mangfoldighed. Det afspejler imidlertid ikke nødvendigvis en tilsvarende reduktion i den indholdsmoessige mangfoldighed, Det vil sige den mangfoldighed, som læseren stifter eller kan stifte bekendtskab med. Og det drejer sig både om den ydre mangfoldighed mellem de forskellige medieorganisationer og det enkelte medies indre mangfoldighed (Horn 2002; jf. Loftager 2004: kap. 7). Specielt er det i denne sammenhæng værd at hæfte sig ved den indre mangfoldighed. Det er nemlig især i kraft af den, at brugeren af mediet bliver konfronteret med den forskellighed af informationer, synspunkter etc., som refleksion og meningsdannelse afhænger af. Dette er også grunden til, at afviklingen af partipressen snarere må betragtes som en fordel end en ulempe. Partipressen kan sikre, at de politiske ledere på egne betingelser kan kommunikere til og med deres tilhængere, ligesom medier med forskellige, partidefinerede politiske linier, vil være ensbetydende med en ydre mangfoldighed, der vil give den enkelte bor- 
ger adgang til alternative informationskanaler. Men som grundlag for et alment tilgængeligt offentligt ræsonnement var partipressen af mere tvivlsom værdi. Den faste loyalitet mod partiet, som ikke blot gjorde sig gældende i opinionsstoffet, men også i nyhedsdækningen (Westerståhl 1992: 101; Thomsen 1988: 99) måtte virke begrænsende på omfanget af den kritiske afprøvning af informationer og argumenter.

Ser man på, hvordan er det så er gået med mediernes mangfoldighed, vidner en undersøgelse af syv danske dagblades nyhedsdækning i en uge i henholdsvis marts 1967 og marts 2001 om, at der både med hensyn til kilder og vinkler er tale om en større indre såvel som ydre mangfoldighed i 2001 end i 1967 (Horn 2002). Det tyder på, at offentligheden i 2001 præsenteres for et bredere udsnit af informationer, vinkler og synspunkter i nyhedsdækning, sammenlignet med 1967.

På den anden side berettiger analysen ikke til en entydig positiv vurdering af mediernes nyhedsdækning. Forfatteren, Line Horn, understreger selv, at analyseresultaterne ikke er ensbetydende med, at der skulle foreligge en "tilstrækkelig“ grad af mangfoldighed (p. 112). Derfor er de heller ikke i modstrid med andre analyser af nyhedsdækningen, som peger i retning af en vis konformitet i medierne (Lund, 2002). Vigtigere end dette er imidlertid, at analyserne ikke efterlader indtrykket af en fastlåst mediesituation. Den skal snarere ses som et resultat af dynamiske processer, hvis udviklingsretning ikke er givet på forhånd.

Selv om man derfor skal være varsom med pessimismen, når det gælder mediernes demokratiske funktion over tid, er det ikke svært at få øje på uheldige træk ved deres måde at fungere på. $\mathrm{Og}$ det drejer sig først og sidst om netop prioriteringen af det politiske spil om magten frem for politikkens substans - altså den fortsatte diskussion af de fælles anliggender og deres politiske behandling, som demokratisk set burde være det primære. Det store paradoks i den forbindelse er, at der om dette 'bør' hersker meget stor enighed blandt samtlige de medvirkende aktører: politikere, journalister og borgere (Lund 2002). Og paradokset skærpes af den omstændighed, at der i alle tilfælde „objektivt“ synes at være grundlag for en anderledes og demokratisk set mere optimal form for kommunikation. Politikerne er blevet frigjort fra 
de mere eller mindre bundne mandater, som tidligere fulgte med repræsentationen af bestemte sociale klasser og fastlåste ideologiske positioner. På deres side er medierne sluppet af med forpligtelsen til forsvar og propaganda for bestemte partisynspunkter, og borgernes politiske meningsdannelse vokser ikke længere ud af deres sociale position og partimæssige identifikation.

Når de hermed forbundne potentialer kun i begrænset udstrækning kommer til udfoldelse, hænger det sammen med de koder, som både parti- og mediesystemet fungerer efter. Både hver for sig, men ikke mindst i deres samspil, fremhæver de systematisk det aspekt af politikken, der drejer sig om spillet om magten. For mediernes vedkommende er det en oplagt måde, hvorpå gængse nyhedskriterier kan bringes i anvendelse, sådan at der sker en prioritering af begivenheder og fakta, der kan tilspidses, forenkles, polariseres, intensiveres, konkretiseres og personificeres (Strömbäck 2000: 157). Et udtryk herfor er interessen for opinionsundersøgelsernes målinger af styrkeforholdet mellem de politiske partier; en interesse, som på paradoksal vis synes at vokse proportionalt med, at de politiske forskelle udviskes. Det samme er en tendens i medierne til som udgangspunkt at forstå og fremstille politikeres udtalelser og initiativer som forsøg på at markere sig i det politiske spil. Og snarere som noget selvfølgeligt end som noget, der kunne være grund til at forholde sig kritisk til.

Med andre ord kan medieinstitutionens nyhedskriterier dermed forstærke den forskydning bort fra sagen og det saglige, som allerede ligger indbygget $i$ det politiske systems egen funktionslogik. Men igen må der holdes fast i, at der dels ingen pressens guldalder er, at vende tilbage til. Dels er der frihedsgrader som tillader, at der under behørig respekt for nyhedskriterierne vil kunne ske en opprioritering af sagen og substansen og en nedprioritering af spillet om regeringsmagten.

Man kan så overveje, hvordan det eventuelt kunne være muligt at påvirke systemerne, så de i højere grad kom til at fungere i overensstemmelse med de altså i høj grad fælles idealer. Som Hjarvard spørger: „Hvis medierne får ansvar for at kontrollere de øvrige politiske institutioner og formidle den offentlige mening, hvem skal så påse, at de udøver denne opgave forsvarligt?" (Hjarvard, 1999: 49). Og i tråd med, hvad der ovenfor er fremgået om 
styringsmulighederne under de givne samfundsstrukturelle vilkår, vil det væsentligst kunne ske gennem påvirkning af kommunikationen i den journalistiske deloffentlighed. I hvert fald er det udelukket, at problemet kan løses gennem direkte politisk styring. Medieområdet er sammen med blandt andet forskning og kunst et hovedeksempel på, hvordan forsøg på politisk regulering, vil virke kontraproduktivt. I stedet for at forbedre, vil den underminere mediernes mulighed for, at varetage deres demokratiske funktioner. Som Hjarvard også er inde på (1999: 49-50), kunne et nærliggende alternativ være, at medierne selv i højere grad begyndte at beskæftige sig med og reflektere over deres demokratiske opgavevaretagelse. Ligesom den gensidige kritik i den videnskabelige offentlighed er den helt afgørende garant for kvaliteten af det, der produceres i forskningsverdenen, kunne noget tilsvarende givetvis være tilfældet, når det gælder medierne formidling af det offentlige ræsonnement $\mathrm{i}$ almindelighed og deres nyhedsdækning i særdeleshed. I et vist omfang ses en sådan fælles kritisk selvrefleksion, men den kunne uden tvivl med fordel fylde betydeligt mere. Tilsvarende efterlyser Hjarvard i sine overvejelser en større åbenhed hos journalister og medier om vilkår og retningslinier for deres egen praksis. Endvidere nævner han som en mulighed etablering af et "mediedemokratiets forbrugerråd“, der løbende kunne have til opgave undersøge og skabe debat om mediernes måde at udfylde deres demokratiske funktioner på.

Hvilken forskel, et sådant råd kunne gøre i praksis, skal jeg ikke forsøge at vurdere. Men det ser ud som et forsøg, det er værd at gøre, og under alle omstændigheder er der behov for, at den offentlige debat om medierne og deres demokratiske rolle øges og forstærkes.

\section{Afslutning}

Hensigten med denne artikel har været at diskutere gældende strukturelle vilkår for og krav til udøvelsen af journalistikkens demokratiske funktion. Fokus har været på ændringerne fra et samfund domineret af vertikale gruppe- og klasseopdelinger til et samfund, hvor samfundsdynamikken væsentligst udgår fra spe- 
cialiseringens og arbejdsdelingens funktionelle, horisontale differentiering. Som konsekvens heraf har politikkens samfundsmæssige opgave og magt ændret karakter. Hvor den før overordnet drejede sig om at fastsætte fordelingen af goder mellem forskellige interessegrupper, handler det nu i højere grad om at realisere det almene vel ved at få autonomt fungerende systemer til at spille sammen. Denne opgave lader sig ikke løse gennem direkte politisk styring, men snarere gennem indirekte påvirkninger, der kan formå systemerne til selv at ændre de ydelser, de producerer, i hensigtsmæssig retning. Og forudsætningen herfor er et levende og virksomt offentligt ræsonnement.

Problemet og paradokset er imidlertid, at logikken, som den fungerer i det politiske system, tilsiger aktørerne, at gribe til mere direkte og bastante former for styring i forsøget på, at fange opmærksomhed og sympati. At politikkens symbolske og taktiskstrategiske aspekter således kommer i forgrunden viser sig ved, at reformer gennemføres uden nævneværdige muligheder for offentlighedens medvirken og i sammenhæng hermed på basis af kun svage begrundelser.

Idet medierne tilsyneladende ligeledes har valgt i voksende omfang, at fokusere på det politiske spil frem for substansen, er de med til at udhule det offentlige ræsonnement, som der ellers er bred enighed om, er deres demokratiske opgave at formidle. Samtidig vil medierne givetvis have mulighed for at påvirke det politiske system i en demokratisk set heldigere retning. Hvordan det kan ske, er et åbent spørgsmål. Sikkert er det dog, at direkte politisk styring er en ufarbar vej. Anskuet systemteoretisk må vejen frem i stedet bestå $\mathrm{i}$ at finde former for påvirkning eller 'irritation' af kommunikationen i den politisk relevante del af mediesystemet, der kan resultere i demokratisk set gunstigere ydelser.

Til slut skal præciseres, at den skitserede systemteoretiske beskrivelse af dagens socio-strukturelle vilkår for demokratisk journalistik naturligvis er valgt, fordi jeg finder, at den indfanger det væsentligste. På den anden side er det klart, at der er set bort fra mange relevante aspekter. Fx kunne man med vægt hævde, at forskellige fordelingsspørgsmål fortsat er af afgørende demokratisk betydning, ligesom spørgsmålet om det flerkulturelle som 
vilkår for demokratisk journalistik også kunne fortjene opmærksomhed. Under alle omstændigheder forekommer det mig af afgørende betydning, at diskussionen af journalistikkens demokratiske rolle gøres konkret. Det vil sige, at den foregår på grundlag af eksplicitte angivelser af karakteren af det samfund, den fungerer i.

\section{N OTER}

1. Jeg har ved tidligere lejligheder behandlet lignende problemstillinger (Loftager 2004, 2005, 2006), og en del af artiklens formuleringer er hentet her fra.

\section{REFERENCER}

Andersen, Simon Calmar (2006). „Styring gennem autonomi? Et forskningsprojekt om politisk styring af de danske skoler“, Politica, 38, 4, pp. 426-445.

Andersen, Simon Calmar (2004). „Hvorfor bliver man ved med at evaluere folkeskolen?", Politica, 36, 4, pp. 452-468.

Christensen, Jørgen Grønnegård (2006). Kronik, Politiken, den 11. juli

Elklit, Jørgen (1986). „Det klassiske danske partisystem bliver til“, pp. 2128 i Jørgen Elklit \& Ole Tonsgaard (red.). Valg og veelgeradfcerd, Århus: Politica.

Feldbæk, Ole (1991). Dansk Identitetshistorie, bd. 1, København: C.A. Reitzels Forlag.

Giddens, Anthony (2003). Modernitetens konsekvenser, København: Hans Reitzels Forlag.

Goul Andersen, Jørgen (1999). „Folket og eliterne. Om meningsdannelse på masse- og eliteniveau“, pp. 52-69 i Jørgen Goul Andersen, Peter Munk Christiansen, Torben Beck Jørgensen, Lise Togeby \& Signild Vallgårda (1999). Den demokratiske udfordring. København: Hans Reitzels Forlag.

Habermas, Jürgen (1992). "Further Reflections on the Public Sphere”, pp. 421-461 in Craigh Calhoun (ed.), Habermas and the Public Sphere. Cambridge: MIT Press. Faktizität und Geltung, Frankfurt a.M.: Suhrkamp. 
Habermas, Jürgen (1992a). Faktizität und Geltung, Frankfurt a.M.: Suhrkamp. Borgerlig Offentlighet, Oslo: Gyldendal Norsk Forlag.

Horn, Line (2002). Mangfoldighed eller konformitet? Specialeopgave, Institut for Statskundskab, Aarhus Universitet.

Jørgensen, Charlotte, Christian Koch \& Lone Rørbech (1994). Retorik, der flytter stemmer. Hvordan man overbeviser i den offentlige debat. Кøbenhavn: Gyldendal.

Knudsen, Tim (2001). Da demokrati blev til folkestyre, København: Akademisk Forlag.

Loftager, Jørn (2006), „Medierne, kommunalreformen og ideen om et offentligt ræsonnement“, Politica, nr. 2.

Loftager, Jørn (2005). „Politisk kommunikation mellem spil og substans: hvordan står det til med det danske demokrati?“, Økonomi og Politik, årg. 78, nr. 3, pp. 29-45.

Loftager, Jørn (2004). Politisk offentlighed og demokrati i Danmark, Magtudredningen, Århus: Aarhus Universitetsforlag.

Luhmann, Niklas (1999). Sociale systemer. København: Hans Reitzels Forlag.

Lund, Anker Brink (2002). Den redigerende magt - nyhedsinstitutionens politiske indflydelse. Århus: Aarhus Universitetsforlag.

Petersson, Oluf, Gudmund Hernes, Sören Holmberg, Lise Togeby \& Lena Wängnerud (2000). Demokrati utan partier? Demokratirådets rapport 2000. Stockholm: SNS Förlag.

Rasmussen, Erik (1969). Ideologi og Politik, København: Gyldendal.

Seip, Jens A. (1958). „Teorien om den opinionsstyrede enevælde“, Norsk historisk tidsskrift, 38.

Strömbäck, Jesper (2000). Makt og Medier. En bok om samspelet mellan medborgarna, medierne och de politska magthavarna, Stockholm: Studenterlitteratur.

Thomsen, Niels (1972). Dagbladskonkurrencen 1870-1970. København: Gad.

Togeby, Lise, Jørgen Goul Andersen, Peter Munk Christiansen, Torben Beck Jørgensen \& Signild Vallgårda (2003). Magt og demokrati i Danmark - hovedresultater fra Magtudredningen. Århus: Aarhus Universitetsforlag.

Westerståhl, J. (1992). „Mediernas roll - TV-Avisen“, i J. Goul Andersen et al., Vi og vore politikere, pp. 98-126, København: Spektrum. 